WIDER Working Paper 2016/150

Senegal-a service economy in need of an export boost

E. Philip English*

December 2016 
Abstract: This paper first summarizes the macroeconomic and trade performance of Senegal, emphasizing the limits of traditional exports. It then focuses on three export sectors which have had some success in the past and have good potential for future growth: tourism, horticulture and information technology-enabled services. Sector-specific constraints are identified including beach erosion and hotel quality (tourism), access to land (horticulture), and lack of competition and skilled labour (information technology). Common problems include the absence of strategies and reliable data, tax administration, and the need for a stronger dialogue with the private sector.

Keywords: exports, services, tourism, horticulture, telecommunications

Acknowledgements: The author wishes to thank Abdoulaye Ndiaye for his help on the information technology sector. He also thanks the organizers and participants of the July 19-20 WIDER conference in Helsinki for their helpful comments.

\footnotetext{
* Consultant, trade and development, Ottawa, Canada, penglish407@gmail.com.
}

This study has been prepared within the UNU-WIDER project on 'Industries without Smokestacks', which is part of a larger research project on 'Jobs, Poverty and Structural Change in Africa'.

Copyright (C) UNU-WIDER 2016

Information and requests: publications@wider.unu.edu

ISSN 1798-7237 ISBN 978-92-9256-194-9

Typescript prepared by Sandra Rawlin.

The United Nations University World Institute for Development Economics Research provides economic analysis and policy advice with the aim of promoting sustainable and equitable development. The Institute began operations in 1985 in Helsinki, Finland, as the first research and training centre of the United Nations University. Today it is a unique blend of think tank, research institute, and UN agency_-providing a range of services from policy advice to governments as well as freely available original research.

The Institute is funded through income from an endowment fund with additional contributions to its work programme from Denmark, Finland, Sweden, and the United Kingdom.

Katajanokanlaituri 6 B, 00160 Helsinki, Finland

The views expressed in this paper are those of the author(s), and do not necessarily reflect the views of the Institute or the United Nations University, nor the programme/project donors. 
Senegal is one of the most stable and democratic countries in Africa. It is the only country in continental West Africa that has never experienced a coup-d'état. ${ }^{1}$ It has enjoyed multi-party democracy since 1976 and has twice seen the defeat of the incumbent President at the ballot box, in 2000 and 2012. There is substantial freedom of the press, and the capital, Dakar, is one of the safest large cities in Africa. The country is proud of its reputation for tolerance and the good relations between its Moslem majority and Christians. It is an open society with strong ties to the West.

The economy has done less well. Senegal is a border-line low income country, with GDP per capita estimated at US $\$ 1,000$ in 2015. ${ }^{2}$ Income per capita has hardly improved since independence in 1960. The oil shock of 1975 and the subsequent debt crisis led to a slow but steady decline. With a fixed exchange rate tied to the French franc, the country was obliged to attempt an internal adjustment, which proved impossible, and finally the currency was devalued — for the first and only time—by 50 per cent in 1994.

The economy grew strongly for the next 10 years, with an average GDP growth of 4.5 per cent per annum. However, there was relatively little structural change, and the rural economy remained dependent on rain-fed crops, which were vulnerable to the unreliable rainfall typical of a Sahelian country. While many African countries experienced a commodity-driven boom after 2005, Senegal suffered a slowdown. The economy suffered from spikes in food and oil prices, the global financial crisis, climatic shocks, a slackening in the reform effort, and worsening governance.

The new government of Macky Sall inherited a sluggish economy in 2012, with a debt-to-GDP ratio of 45 per cent and a fiscal deficit of 6.7 per cent of GDP. It immediately committed to the restoration of sound macroeconomic management with an IMF Policy Support Instrument. The fiscal deficit has been reduced to a projected 4.2 per cent in 2016. The CFA franc is managed by a relatively independent, regional central bank, which has maintained low inflation and generally avoided an overvalued exchange rate. ${ }^{3}$ The advantages of a sound monetary policy, ease of transactions between member states, and the absence of exchange rate risks, are generally considered to outweigh the constraints of a fixed exchange rate regime.

When the Doing Business ranking for Senegal fell to 176, the government committed to an ambitious three-year programme of reforms, which has been successfully implemented. Its ranking in 2015 was 152, albeit still very low. Senegal's ranking in the corruption perception index has improved from 112 to 61. GDP growth gradually strengthened to 6.5 per cent in 2015, thanks in part to good weather conditions. The IMF forecasts that it will be the third fastest growing economy in sub-Saharan Africa in 2016, with continued growth at 6.6 per cent. ${ }^{4}$ By early

\footnotetext{
1 The island country of Cabo Verde also enjoys this record.

${ }^{2}$ Senegal was classified as a lower middle income country in 2014 until the appreciation of the US\$ caused a decline in its GDP per capita in US\$.

${ }^{3}$ This is the general conclusion of the IMF, though it might change if the US dollar weakens.

4 This seems a little optimistic since it is unlikely that agriculture will grow much and may even fall a little.
} 
2016, Senegal was one of only two sub-Saharan African countries to enjoy a positive outlook from the rating agencies. ${ }^{5}$

Figure 1: Sectoral Contributions to GDP growth (LHS: \% of total, RHS: percentage points)

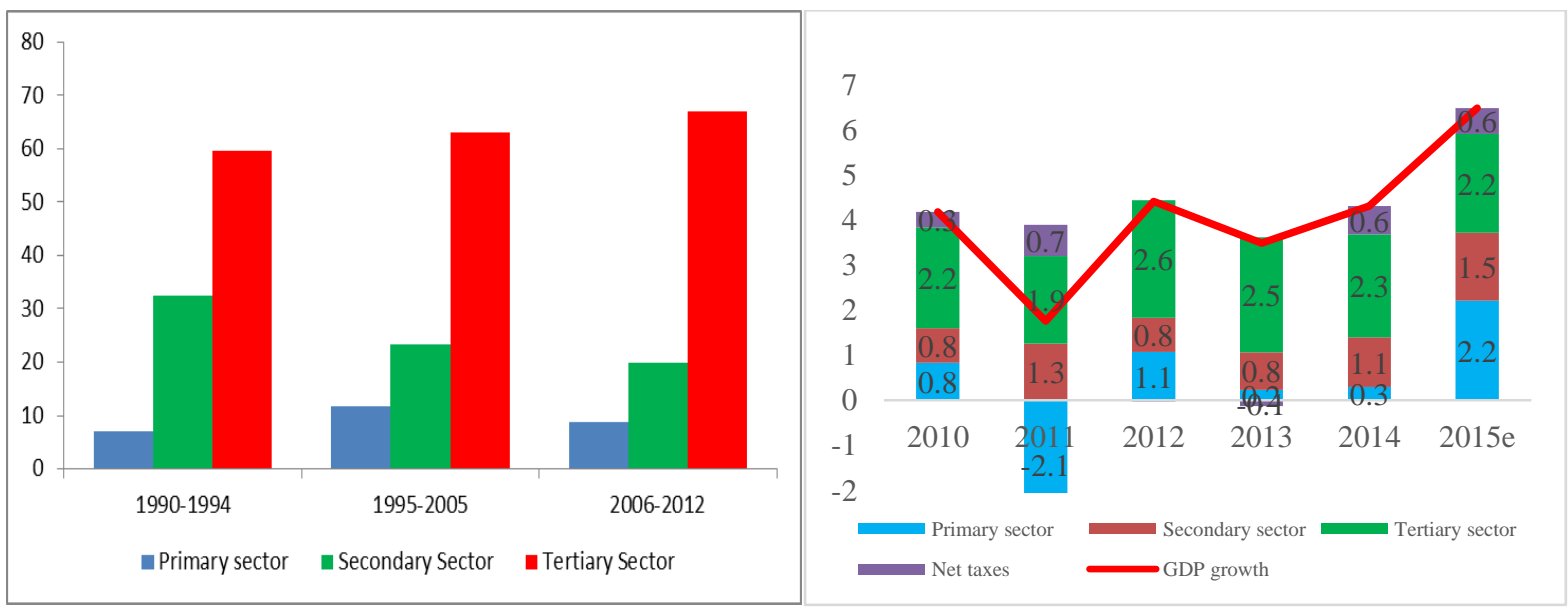

Source: World Bank (2014, 2016).

Today, Senegal has a diversified economy driven by services. The tertiary sector has accounted for 60 per cent of GDP and 65 per cent of GDP growth since 2005, led by telecommunications and finance. In the secondary sector, construction has been the most dynamic, but the mining sector has gradually expanded with new mines in gold and mineral sands. Manufacturing represents 12 per cent of GDP. The primary sector is small by African standards, at 15 per cent of GDP, but it is diversified between crops ( 8 per cent), livestock ( 4 per cent), and fishing ( 3 per cent).

\section{Trade performance}

Senegal's exports of goods and services as a share of GDP fell to 25 per cent by 2014, below the average of 30 per cent for sub-Saharan Africa. Exports of goods have typically covered only half of merchandise imports. Services trade also records a small deficit. However, the diversity of the economy is reflected in the structure of its exports. No single good accounts for more than 10 per cent of total exports of goods and services. The largest commodity export is a wide variety of fish products, both industrial and artisanal. Manufactured goods, including petroleum products, cement, phosphoric acid, and fertilizer amount to almost half of all goods exported. Tourism appears to be the largest single foreign exchange earner, though the data is not reliable. Other business services, which include business process outsourcing, are the next largest service export and the sixth largest export overall.

\footnotetext{
5 The other one was Côte d'Ivoire.
} 
Table 1: Principal Exports of Goods and Services: Share of total, 2014-15 (\%)*

\begin{tabular}{lr}
\hline Other manufactures/equipment & 11.6 \\
Tourism & 10.9 \\
Fish products & 9.3 \\
Petroleum products & 9.2 \\
Gold & 8.0 \\
Cement & 5.0 \\
Other business services & 4.9 \\
Phosphoric acid and fertilizer & 4.2 \\
Transport services & 3.8 \\
Groundnut products & 2.6 \\
Horticultural products & 2.4 \\
Other goods & 13.7 \\
Other services** & 13.4 \\
\end{tabular}

${ }^{*}$ Average of 2014 and 2015 for goods; 2014 for services.

**Over half consists of telecommunications services which are essentially taxes on incoming long-distance calls. Source: BCEAO (2014); République du Sénégal (2015).

The four traditional exports have been fish products, groundnut oil, tourism, and phosphoric acid and fertilizer. Fish products suffer from serious over-fishing and are unlikely to sustain significant growth until stocks can be replenished. Groundnut oil has been hampered by fluctuating supplies of raw material due to irregular rainfall, declining soil fertility, mismanagement throughout the value chain, and declining world demand for groundnut oil. Tourism did well until 2000, after which it has suffered from neglect. Phosphoric acid and fertilizer have enjoyed some growth, and may be able to support further expansion under new ownership of the existing mine and the opening of one new mine.

New exports have emerged, notably petroleum products, gold, and cement. Petroleum products involve little value-added, however, as they depend on imported crude oil, which is processed at a small and inefficient refinery. There is no potential for growth here, at least until newly discovered off-shore oil and gas reserves are developed. The recent slump in prices suggests that this may not happen soon. Gold production began in 2006, and it is likely that new mines will open. Cement has registered rapid growth, drawing on local limestone deposits. In general, however, Senegal is not considered to have major mining potential. The last notable merchandise export is fresh fruits and vegetables. These remain modest in size, but have enjoyed the fastest growth in the last 10 years.

Exports of business services have grown steadily over the last ten years, and do not face any fundamental supply or demand-side constraints. Transport services have also grown, albeit more slowly. The port has been relatively well-managed and transit trade to Mali benefited from the crisis in Côte d'Ivoire, the major competing transit country. On the other hand, the national airline has suffered from continued mismanagement and was effectively bankrupt by late 2015 . The rail link to Mali has steadily deteriorated, to the point where the operating concession was rescinded in 2015. With the stabilization of Côte d'Ivoire and the location of Senegal on the extreme west end of West Africa, the prospects for expanding transit trade appear limited.

The government has high hopes for a special economic zone that it is developing near the new airport just outside of Dakar. The Chinese have begun to build one industrial zone nearby and are committed to experimenting with some labour-intensive manufactured exports. Senegal 
would seem well-suited given its proximity to Europe and America and its good port facilities. However, it remains a high-cost business environment, with burdensome labour regulations. One hopes that this will materialize and expand in scope, but many observers are sceptical.

Clearly there are more than two or three export sectors that have the potential to drive this economy. Senegal is indeed fortunate to have a variety of assets on which to draw. But three of the sectors that have a proven track record and plenty of up-side potential are tourism, information and communication technology (ICT), and horticulture. All three are highlighted in the government's new development strategy, the Plan for an Emerging Senegal (PES). This paper will focus on these three sectors.

\section{Tourism}

In the 1980s, Senegal was second only to Kenya in sub-Saharan Africa in terms of tourist arrivals. This was based on its beautiful weather during the European winter, extensive beaches, proximity to Europe, its peaceful environment, cultural attractions and reputation for hospitality. Club Med was operating two resorts and a new tourism station had recently been developed at Saly-Portudal, attracting investors who steadily expanded the hotel capacity. However, by 2010, Senegal was no longer in the top ten destinations in sub-Saharan Africa.

While tourism has boomed in many countries, it has faded in Senegal. This is due primarily to neglect rather than to any fundamental problems and the future should be bright.

Figure 2: Tourism has been declining since 2002

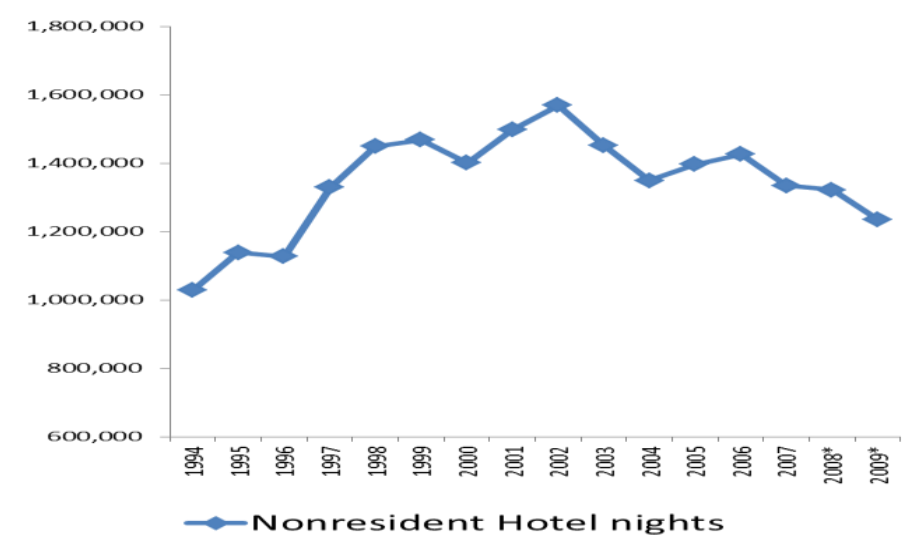

Source: Senegal, Ministry of Finance, Economy and Planning, Direction de la Planification et des Études Économiques website.

The analysis of the tourism sector is hampered by a lack of data. This is rather surprising given its role as one of the top sources of foreign exchange, but symptomatic of the degree of interest shown by the authorities. Official statistics on tourism arrivals, drawn from the main hotels, end in 2010. They indicate that non-resident arrivals gradually increased to a peak at 492,000 in that year. However, non-resident nights peaked in 2002 at 1,569,000 and declined thereafter to only $1,234,000$. The only data available after 2010 is for visitors arriving by plane, and this indicates no improvement up to 2013 and a dramatic fall in 2014 to 374,000, reflecting the Ebola scare. 2015 is unlikely to have been any better since the threat of Ebola affected the 2014/15 tourism season. 
The only detailed study of the economic impact of tourism in Senegal dates from 2003, and this benefited from technical support from the World Tourism Organization. ${ }^{6}$ It estimated the direct contribution of tourism at 4.6 per cent of GDP, or 6.8 per cent once indirect benefits are included. However, this includes domestic tourism, transport, and public spending related to the tourism industry. The overall contribution of foreign tourists' spending in Senegal would be closer to 4.3 per cent of GDP. The number of tourist nights was adjusted in the study to include small hotels and campements not covered by the survey of main hotels, along with stays with friends and relatives, and long-term visitors who typically come for several months during the European winter. The latter has become an important, and somewhat overlooked, phenomenon in Senegal, and may now account for tourist nights equivalent to 20 per cent of those in hotels. ${ }^{7}$ However, the clients of small hotels are more likely to be nationals or other African visitors on business. The study also highlights the likelihood of under-reporting by hotels, but the correction made seems excessive. ${ }^{8}$ The impact of international tourism was probably no greater than 4 per cent of GDP in 2000 and has probably declined closer to 3 per cent in 2015.

That said, it is worth underlining that such tourism brings significant benefits to the local economy, to respond to a debate that unfortunately continues to linger in some circles, including with the previous President of Senegal. The 2003 study estimated the import content of tourism spending at 30 per cent. This is roughly consistent with a more detailed study conducted for the year 1979, which estimated this figure at 36 per cent, when the economy was somewhat less developed. ${ }^{9}$ The impact on employment is also significant, though again data is lacking. Global evidence suggests that on average in developing countries, each hotel room creates one hotel job, one more job in the rest of the tourist industry, and one job through indirect linkages. ${ }^{10}$ With 10,000 hotel rooms, this implies roughly 30,000 jobs, of which 90 per cent can probably be attributed to foreign visitors. ${ }^{11}$ This contribution is especially noteworthy given that much of this employment is located outside of Dakar, where alternatives are limited.

The fall in the total number of nights spent in hotels reflects a decline in the average length of stay to only 3.2 nights. Given the increase in arrivals, this suggests that business tourism has been expanding while longer-stay holiday tourism has declined. Unfortunately, this level of detail is not available in the statistics but it is confirmed by actors in the industry. New hotels have opened in Dakar and the top ones have recently expanded their capacity. In addition to normal business tourism, Dakar is a popular site for conferences. The last available survey conducted in 2000 indicated that 39 per cent of tourist nights took place in Dakar, where it was assumed that the purpose was essentially business and conferences. This share has undoubtedly increased since then. Since business tourism is doing well and is more a bi-product of other activities in the economy, our focus is on leisure tourism. However, the potential to expand conference tourism must not be overlooked.

Saly-Portudal is clearly suffering, as is the other main beach destination, Cap Skirring, in the Casamance. Several hotels have recently closed, and others have deteriorated in quality, as low profitability has impeded their capacity to conduct regular maintenance, let alone upgrade their

\footnotetext{
${ }^{6}$ République du Sénégal (2003).

7 There are 33 'residences' in Saly-Portudal alone, each with roughly 40 villas.

8 The total number of hotel nights is estimated at 2.6 million.

${ }^{9}$ English (1983).

${ }^{10}$ English (1986: 38).

11 The 2003 study by the Government estimates total employment at 100,000 but this seems too high. République du Sénégal (2003).
} 
products. Hotel operators have relied increasingly on seminar business, since Saly-Portudal is only 1.5 hours from Dakar, along with small but growing local tourism during the school holidays in the off-season. In the more distant Casamance, unofficial estimates point to a decrease in arrivals from 60,000 in 2000 to only 20,000 today.

The reasons for this are many. The 2008-2009 global financial crisis hurt demand in Europe, and the insecurity in Casamance affected its attractiveness. Yet, the crisis in North Africa and the Middle East should have worked to Senegal's advantage; the only security incident in the Cap Skirring region occurred in the early 2000s. Something more fundamental is clearly at work. In essence, the product has become tired and the government has done little or nothing to support it—on the contrary, it has taken some measures that have hurt the industry.

Senegal offers a variety of attractions, from sport fishing and bird watching to village stays and art festivals. However, most of the holiday business is anchored on fairly low-cost beach tourism, in the context of an exotic but low-risk African setting. This worked well for a while. But global demand has gradually evolved to higher quality products, along with more emphasis on adventure, culture and other forms of tourism. And though the demand for low-cost beach tourism remains important, notably post-2008, Senegal has had trouble competing with other destinations on the basis of price. Its strong currency, tied to the Euro, has put it at a disadvantage relative to neighbouring The Gambia. Cabo Verde, which also has a strong currency, has relied on all-inclusive packages in large-scale hotels owned by tour operators who ensure competitive air transport costs. Senegal has relied more on scheduled flights and, with limited airline competition, notably in its main French market, costs have been high. This problem has been aggravated by surcharges intended to finance a new airport that has taken eight years to build and was still not complete in 2016. The extra cost of reaching the Casamance by air is also cited as a major factor in the decline of this segment of the industry.

Pre-2000, Senegal drew from a wide variety of markets, but with a lack of destination promotion or investment in hotel assets, the non-French markets started to decline. Increasing competition in the French market led to price competition, reduced margins and a further contraction of investment. Senegal lost its image as an 'exotic' destination and became a mass-market product. ${ }^{12}$ Meanwhile, the Saly-Portudal product suffered from beach erosion and a general lack of planning or regulation. The resort became crowded and poorly maintained, and tourists regularly complained of harassment by itinerant hawkers. Prime beach locations were sold for private residences, hotels were allowed to build infrastructures that aggravated the erosion, and nothing was done to protect the beach.

The previous President, Abdoulaye Wade, who held power from 2000 to 2012, made it clear that he did not believe that tourism benefited the country and therefore had no intention of providing significant support for it. This attitude prevailed in spite of the fact that the 2006 Accelerated Growth Strategy identified tourism as a priority sector. Senegal has paid a heavy price for this neglect.

The new government of Macky Sall has reversed this position. However, its actions have sent a mixed message. The ineffective tourism promotion agency was closed down, but responsibility was transferred to the private sector, which was too weak to provide effective leadership. A complicated online biometric visa system was introduced for all visitors, and this had to be completed in advance of departure. Funding for control of beach erosion disappeared, and a new strategy was developed, albeit with little input from private sector leaders. These problems were

12 World Bank (2015a). 
then compounded by the Ebola scare, which discouraged many tourists from going to any West African destination for the 2014-15 season.

Nonetheless, the Sall government appears to be slowly improving its approach. The tourism industry in the Casamance was given a 10-year exemption from all taxes. The reduced VAT rate of 10 per cent applying to hotels in the rest of the country was extended to tour operators. Minor reductions in some of the airport taxes have been made. Small sums have been allocated to begin the rehabilitation of Saly and a project has been launched to counteract beach erosion, with World Bank funding. New airlines have been encouraged to provide services to Senegal, notably in the key French market. Government resources are also being devoted to the infrastructure needs of a new beach resort. Most significantly, the President admitted that the new visa system was a mistake and it was rescinded.

In early 2016, there were several promising signs of recovery in the holiday segment of the industry. The Ebola scare had ended and bookings were increasing for the upcoming season. The few higher-end hotels were doing well, demonstrating that Senegal remained attractive if the product was well-managed. This was further confirmed by the decision of Club Med to buy and upgrade a beach hotel that had been closed for many years. The new airport was nearing completion, as was a new highway to link it to Saly. ${ }^{13}$ Together, this infrastructure should make the arrival and departure experience much easier when completed. Unfortunately, a new external shock appeared. Terrorist attacks in hotels in Burkina Faso and Mali, followed by an attack at a beach outside Abidjan in Côte d'Ivoire, have the industry worried once again.

\section{Where to from here?}

There should be no doubt that demand will expand for the products that Senegal can offer. Rising incomes will enable more and more people to travel internationally, and traditional destinations such as the Canary Islands are becoming saturated. ${ }^{14}$ The instability in North Africa and the Middle East is, regrettably, likely to continue for some time. Cabo Verde has managed to surpass Senegal in tourist nights on the basis of two small islands with little more than sun and sand. Senegal offers a special opportunity to discover Africa with minimal risk, combining sun and sea with adventure, nature and culture. It is sometimes described as 'Africa for beginners'. But past trends and attitudes must change in order to make this a reality.

The renewed commitment to tourism by the current government is probably the single most important step required to move forward. However, the industry is a complicated one, which calls for a sophisticated understanding on the part of the authorities across various ministries and levels of government, a close and constructive partnership with the private sector, and wellthought-out priorities. Unfortunately, the tourism ministry is weak, its leadership changes frequently, the dialogue with the private sector is inadequate, and the current strategy lacks strategic vision and prioritization.

The top priority would seem to be saving Saly. This is the foundation of the leisure tourism industry and the one known by global tourism actors. At present it does not portray a positive image of Senegal. The beach needs to be rebuilt and protected, the hotels renovated and properly classified, the town cleaned up, and the harassment ended. The situation is so dire that some

\footnotetext{
13 The final date for completion of the airport remains uncertain but, in the interim, improvements have been made to the old airport.

14 They currently receive nine million tourists annually.
} 
senior officials appear to turn their back on Saly and focus instead on the development of new resorts farther down the coast. This is also the impression given by the PES. Fortunately, a new World-Bank-funded project is focusing on Saly, in particular the beach problem. ${ }^{15}$ It is also financing several integrated destination development plans, including one for the Saly-Portudal region. This is probably more useful than revisiting the national tourism strategy.

At the national level, a new tourism promotion strategy is needed to reposition Senegal internationally, emphasizing not just its weather and beaches, but also its stability, culture, and the variety of adventures that it can offer in a truly African setting. This should include a concerted campaign to reassure tourists of the safety of Cap Skirring in the Casamance. ${ }^{16}$ It should also reduce the dependence on the French market. A new tourism promotion agency has been created, but its capacity needs to be built up and it should be managed in a true partnership with the private sector. It will need to be combined with an air transport strategy that increases competition and accesses new markets. Much better data must be collected to guide the development of the sector. ${ }^{17}$

New tourism resorts, as called for in the PES, are needed in order for the industry to expand. These should learn from the experience of Saly-emphasizing higher quality hotels, protecting the beaches, working closely with the local community, and managing the growth in peripheral activities. The plan to make Pointe-Sarène an eco-friendly resort of high-end hotels is a good one, and in keeping with evolving trends in the industry.

The new airport needs to be completed and opened as soon as possible. This would enhance the experience of the tourists and improve the country's image generally. It would also help the new conference centre, which needs business to justify its large investment costs. Completing the nearby airport will improve the attractiveness of the conference centre, especially if it encourages the establishment of new hotels in the vicinity. ${ }^{18}$

Finally, but most difficult of all, the authorities need to do whatever they can to avoid a terrorist attack. Hotels have strengthened their security measures, as has the main shopping centre. In any event, this threat should not distract the authorities from a long-term commitment to expanding this sector. Tourists will eventually come back even if there is an incident, and tourism offers one of the best options for job creation and poverty reduction in many regions of the country.

\section{$4 \quad$ Horticulture}

Some of the attributes that underpin Senegal's tourism industry are also conducive to the development of horticulture exports. The warm, sunny weather during the European winter makes Senegal well-placed to provide off-season fruits and vegetables. Its proximity to Europe and its direct access to the ocean make it the closest potential tropical supplier (after Mauritania) with the option of lower cost maritime transport. ${ }^{19}$ Its openness to foreign investors is a third

\footnotetext{
15 The World Bank Exports and Competitiveness project was due for approval in 2016.

${ }^{16}$ Part of the problem is the classification of Casamance as high-risk by the French Foreign Ministry. This not only discourages tourists but raises the cost of insurance for the airlines.

17 The new World Bank project also has components to support tourism promotion, public-private dialogue and data collection.

${ }_{18}$ Currently conference participants have to travel from hotels in downtown Dakar some $30 \mathrm{~km}$ away.

${ }^{19}$ So far, attempts to develop horticulture exports from Mauritania have not succeeded.
} 
critical advantage. The lack of rain could pose a problem; however, groundwater is adequate in areas close to Dakar and the Senegal River provides ample irrigation potential in the northern part of the country.

Exports remained modest up to 2003, with volumes in the range of 10,000 tonnes, and products dominated by green beans. Starting in 2004, exports to Europe grew rapidly, averaging increases of 20 per cent per year for the next decade. Another 4,700 tonnes were exported within Africa, primarily to Côte d'Ivoire and Morocco. The product range has diversified significantly. Melons, watermelons, and cherry tomatoes now surpass green beans by volume, while mangoes and sweet corn are now comparable to green beans. Exporters are experimenting with a wide range of other crops (e.g., sweet potatoes, green onions, and radishes).

The sector is dominated by integrated multinational companies that handle production, processing and exporting, with distribution channels in Europe, selling either to wholesalers or directly to supermarkets. Production typically takes place on commercial farms, in order to ensure the complete control over the production process necessary to meet phytosanitary standards. Smallholders only remain significant in the case of mangoes and green beans.

Figure 3: Senegal: Horticulture exports to Europe by Volume (tonnes)

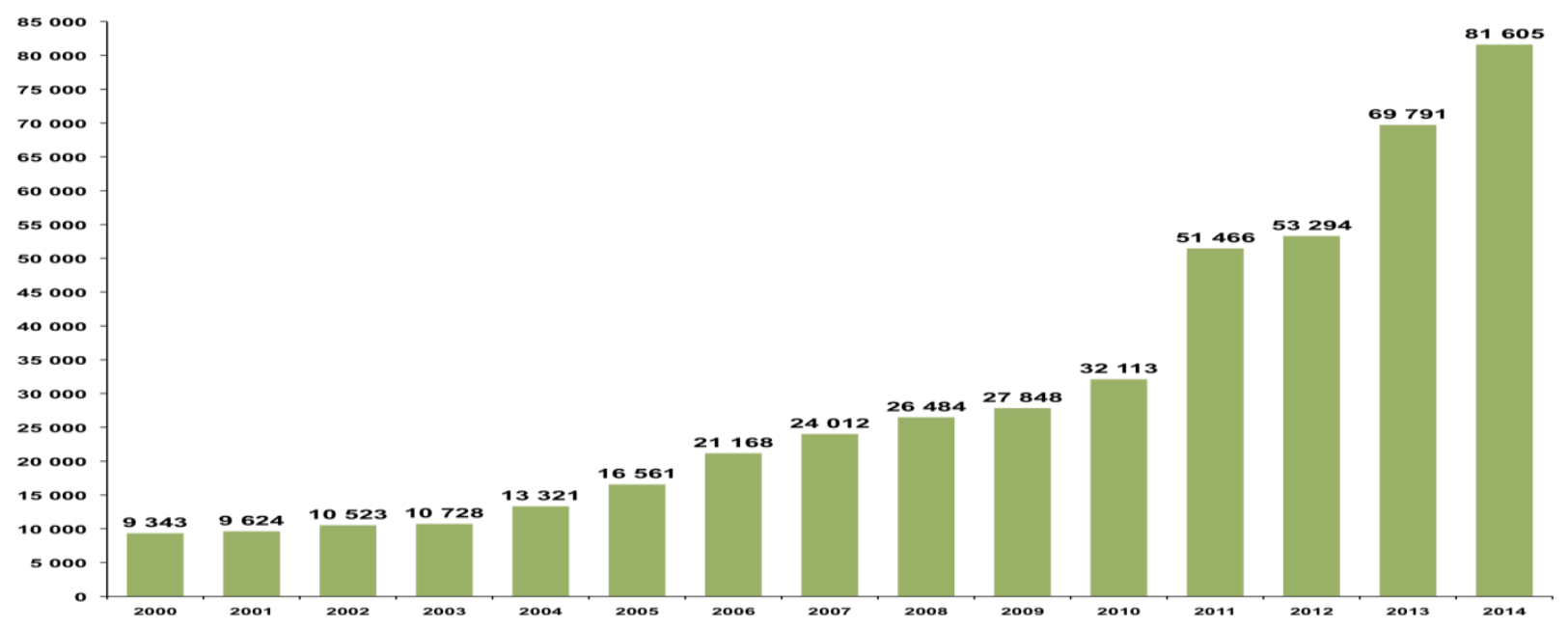

Source: Eurostat online.

Horticulture exports remain very small as a percentage of GDP, in the order of 0.5 per cent. But they are now comparable to groundnuts in terms of export value, exceeding the latter in years of poor rainfall. More importantly, their rapid growth stands in sharp contrast to the decline in groundnuts. Groundnuts still occupy far more people, but many of these will have to exit, given the low productivity and poor market prospects. Horticulture export farms offer an attractive alternative, as summarized in Box 1. 
Box 1: The impact of horticulture exports on poverty and women in Senegal

In 2005 and 2006, independent researchers from Belgium analysed the impact on poverty of horticulture exports from Senegal. Their initial working assumptions were not positive, as reflected in the title of their subsequent paper, 'Globalization and Poverty in Senegal: A Worst Case Scenario?' First, they looked at employees working for the industry leader in northern Senegal. To their surprise, households with an employee at this company had lower poverty rates ( 35 per cent) compared to other households in the same village (46 per cent), even though the former households were larger and had less land on average, and should therefore have been poorer. The difference in extreme poverty was even more marked, 6 per cent vs 18 per cent. Their total income was twice as high, and even their income from farming was higher.

\section{Comparison of households with and without members employed in the tomato export industry*}

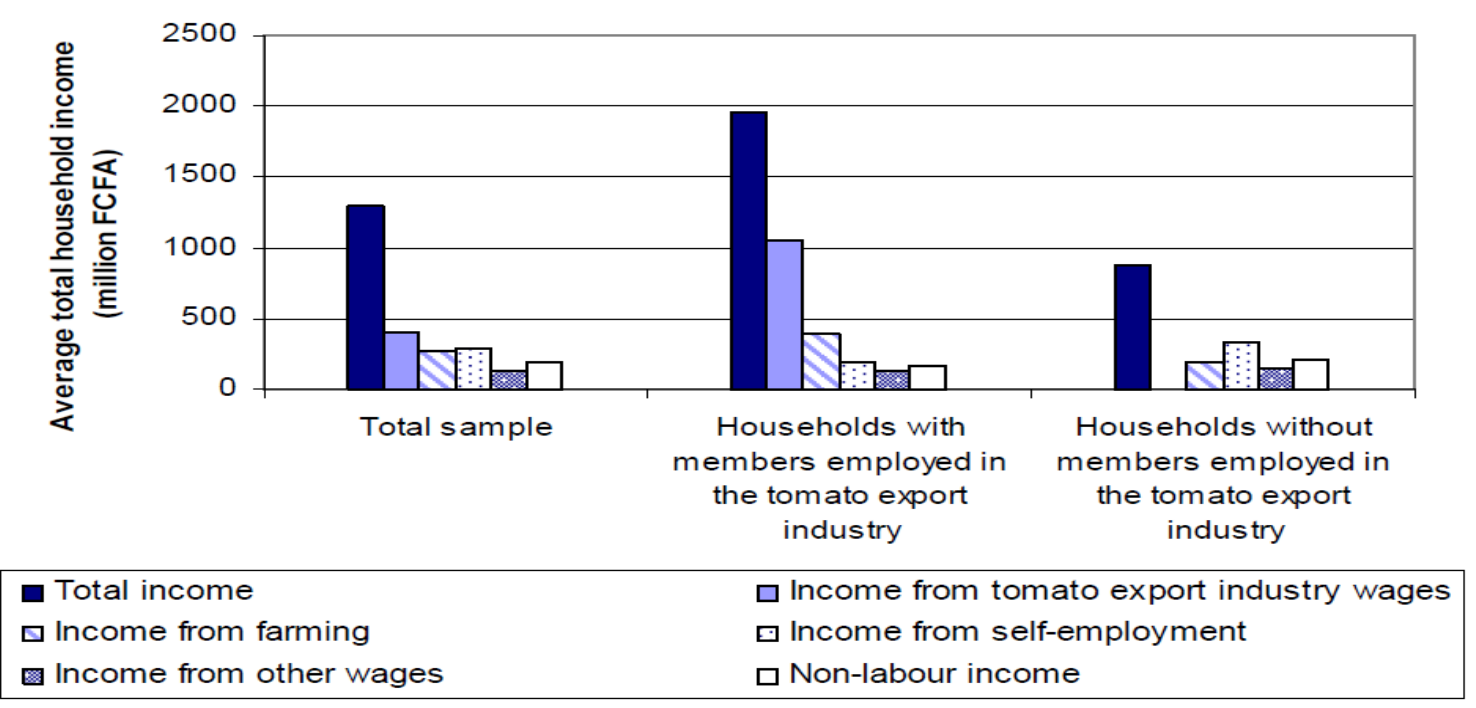

*The label for the y axis should read thousands and not millions.

Similar results were found in their second study of employees in nine green bean exporting farms in Les Niayes, just north of Dakar. This result is due to the fact that most of the work on these export farms takes place during the dry off-season of October to May, when demand in the European market is strong. Since there is little to do in rural Senegal during this time, the opportunity cost of labour is very low. Employees are then free to return to their farms when the rains come back in July. The researchers also point out that much of the benefit is captured by women, who tend to dominate the workforce on export farms. They speculate that it is better for women to work as employees rather than on their own farms under contract with commercial farms, since such contracts are typically signed by the male head of the household, even though the women will do much of the work. By working as employees they are likely to have more control over the income earned. However, they were unable to test this hypothesis.

Sources : Maertens, Cohen and Swinnen, 2008a; Maertens and Swinnen, 2008b.

One of the keys to the early expansion of this sector was the arrival of Grands Domaines du Sénégal (GDS), an affiliate of Compagnie Fruitière, in 2003. The parent company was best known for exporting bananas and pineapples from Cameroon and Côte d'Ivoire, and had developed special high-speed ships to bring these goods to northern European markets. With excess capacity, they decided to develop a side-business in Senegal, which was on the route. The country was not suitable for their traditional products so they launched a completely different cherry tomato operation in the Senegal River valley. While they coped with many problems, they invited other exporters to use their ships, and at least one was given access to their refrigerated containers at Farmgate. The sector was able to shift from air transport to maritime, significantly 
improving its competitiveness. Thus, the transport dilemma was resolved for more than half of all horticulture exports, along with the availability of other ships, and more recently the option of road transport. ${ }^{20}$ In contrast, transport problems have led to the demise of many exporters in neighbouring The Gambia. Maritime transport accounted for 77 per cent of total exports to Europe in the 2014/15 season, and road transport, 18 per cent, while air transport is marginal (5 per cent).

The second typical problem for such activities is access to land. Indeed, it was for this reason that GDS moved its initial operation from the Mauritanian side of the Senegal River. This had not proven to be a major constraint up to 2014, given the small land requirements and low population density, especially along the Senegal River valley. However, the arrangements were often unstable and occasionally precarious. Few exporters had land titles, and some simply made informal agreements with a village to use land in return for certain promises. The most common solution was to convince a village to transfer land to the government, which was then in a position to sign a long-term lease with the exporter. But this meant that the community lost control of the land and did not necessarily receive any direct benefits, other than the prospect of jobs. Exporters have generally maintained good relations with their communities, though a large biofuel project in the Senegal River valley did not do so well and this may have set off alarm bells. Also new foreign investors are looking for more secure arrangements. Access to land appears to be the main factor explaining the lack of growth observed in $2015 .^{21}$

The government has been working with the World Bank to find a solution to this problem without waiting for full-fledged land reform, and they think they have an answer. Rural land is generally classified as Domaine Nationale and controlled by rural communities through their rural council. This land can be converted to Domaine Prive de l'Etat (private land of the State) and then leased to private operators. The new proposal involves returning such land to the community, and then allowing the community to sign a sub-lease with an investor. Part of the annual lease payment will go to the community and part to the government. A World Bank project will provide technical assistance to the communities to assist them in negotiations with investors. This arrangement has the advantage of not requiring a change in the law, although it did necessitate some new implementation decrees. It has taken longer than hoped, as the government moved cautiously to avoid a backlash, but it was ready for a test in $2016 .{ }^{22}$

A third problem was related to taxes, specifically value-added tax. This came to a head in 2012 in the context of a general tax reform and was only resolved by intervention from the President. The problem has re-emerged in 2016 and may yet discourage some new investors, who are not being offered the same advantages as existing exporters (see Box 2).

\footnotetext{
${ }^{20}$ Recently, some exporters have found that the higher cost of trucking through Mauritania and Morocco can be offset by the greater flexibility, since trucks can depart at any time, while goods may have to wait up to five days for the next ship. This improves the product's shelf life for clients.

${ }^{21}$ In addition, the biggest fruit exporter cut back on production for fear that the Ebola scare would hurt demand.

22 The World Bank supported three rounds of consultations with all villages in the project area, in collaboration with local NGOs. While the communities were all supportive, some NGOs continued to express concerns over potential land-grabbing. The project, called Senegal: Sustainable and Inclusive Agribusiness, was approved in 2013.
} 


\section{Box 2: VAT reimbursement-the Achilles' Heel of the VAT system ${ }^{23}$}

In 1997 the Senegal government created a special status for enterprises exporting at least 80 per cent of their output, called the Entreprise Franche d'Exportation or EFE. Among other things, this allowed companies to import inputs without paying the 18 per cent value-added tax. This was judged to be appropriate since these companies would not be receiving VAT payments on their exports and would therefore be eligible for reimbursement by the government, but the reimbursement process typically led to long delays, which could seriously impact cash flow and profitability.

Over the years, many enterprises obtained this status without meeting the minimum export criteria or even exporting at all. In 2012, the government proposed to end the special regime as part of an overall exercise to reduce tax exemptions. However, legitimate exporters in the horticulture and fishing sectors were concerned that this would threaten their viability and pointed out that some of them had invested on the basis of the 25year commitment made by the government in 1997. After appealing directly to the President, their status was preserved. The exporters then offered to work with the authorities to weed out ineligible beneficiaries, explaining to the authorities exactly what documentation should be requested from all EFE status holders and why. In the end, the number of EFE companies was reduced from 439 to 77.

However, continued concern over tax exemptions in 2015 led to a tightening of the rules for existing EFE companies and a decision to stop offering EFE status to new investors. Given that the process of VAT reimbursement is still not working well, it would seem advisable to concentrate on removing cheaters while continuing to facilitate legitimate exporters.

\section{Where to from here?}

Exporters describe Senegal as virgin territory for horticulture exports. Even though there are more than 20 exporters, most are small and Senegal's share of the European market is tiny. Horticulture has been the fastest growing category of global agricultural trade, along with fish products, and expectations are that it will continue to expand. Senegal enjoys ideal conditions for fruit and vegetables, and could also re-enter the floriculture market. ${ }^{24}$ Horticulture is one of the top sectors of interest to new foreign investors.

The current government clearly understands the importance of this sector, and it figures prominently in the PES. ${ }^{25}$ Now it needs to strengthen its role as facilitator without frustrating the dynamism of the private sector. First and foremost is the land issue. As in most other countries, access to land is a highly sensitive topic, and it has become especially controversial in recent years due to unfortunate examples of 'land-grabbing' in other African countries. The authorities must find a way to provide investors with secure access to land while protecting the legitimate interests of the local population. This process appears to be well underway.

Water is the next critical input. It should not be a major constraint in the Senegal River valley, except around the Lac de Guiers. This lake, fed by the Senegal River, is the only lake of any size in Senegal. It provides two-thirds of the drinking water to Dakar and also supports the only sugar plantation in the country. Horticulture exporters are now locating around the lake. At some

\footnotetext{
23 This expression comes from IMF (2005).

${ }^{24}$ Kenyan exporters have recently visited Senegal to explore the options.

25 The Minister of Agriculture has made it clear that he would prefer to focus on horticulture rather than groundnuts, but the latter's problems cannot be ignored.
} 
point, the authorities may have to choose between the expansion plans of the sugar company and the development of horticulture. ${ }^{26}$

The authorities would also be well-advised to resolve the VAT reimbursement issue as rapidly as possible, either by continuing to offer EFE status to new investors, or by finally implementing an efficient reimbursement mechanism. Port facilities could be further improved, perhaps with the establishment of a special terminal for fruit and vegetables. The proposed bridge over the Senegal River at Rosso would facilitate the alternative of road transport. Finally, the dialogue with key private sector operators, foreign and domestic, needs strengthening in order to identify and resolve critical problems before they become serious.

\section{Information and Communication Technology (ICT)}

The communications sector has been the fastest growing part of the economy, averaging over 10 per cent per year, thus its share of GDP has increased from 3.5 per cent in 1995 to 6.7 per cent in 2013. This is close to the total contribution of crop agriculture (8 per cent on average, less in years of drought). And this probably does not include some activities typically associated with ICT such as software development. Most of this growth has been driven by services for the domestic market, notably through the rapid expansion of mobile phones. But exports have also been important.

Senegal was one of the earliest entrants into outsourcing in sub-Saharan Africa. This reflected its reputation for economic and political stability, a well-educated workforce, investments in telecommunications infrastructure, as well as the usual cost advantages. Call centres were the main focus, and companies were able to attract better qualified employees than in France, at onetenth of the cost. ${ }^{27}$ By 2000, 35 companies exporting IT-enabled services were operational. While call centres have constituted the dominant source of ICT exports, Senegalese companies are involved in a full range of other exports, including data processing, the design and maintenance of applications and websites, systems integration, and software development. Much of this trade is focused on West Africa, especially the higher value-added services.

There are numerous success stories that underline the potential for further growth. The largest call centre company, Premium Contact Center International (PCCI), now has branches in seven other African countries, two offices in Europe, and headquarters in Dubai (see Box 3). On a smaller scale, Samres AB has trained Senegalese to speak enough Swedish to arrange transport services for the disabled in Sweden. Pictoon developed the first African animated TV series, which was sold to several African TV companies. ${ }^{28}$ A private-public partnership between the customs agency and ICT companies led to the development of ORBUS, a single window for trade facilitation, which has now been adopted in Burkina Faso, Togo, and Kenya. Chaka Computers has developed a money transfer system that is competing with Western Union. And in 2016, the French company, Atos, established a large operation in Senegal, initially to develop a new financial information management system for the finance ministry, but with the intention of exporting this expertise to other African countries.

\footnotetext{
26 The sugar company is the largest single employer in the region, but it depends on high protection.

${ }^{27}$ ILEAP, 2014.

${ }^{28}$ This company has since closed, but several of its artists have gone on to set up their own companies and a program has been created to train animation specialists from across Africa.
} 


\section{Box 3: PCCI: First Call Centre of Africa and More}

PCCI was founded in 2001 by three Senegalese entrepreneurs. Its first call centre was created in Dakar in 2002. Since then it has grown steadily, both in geographic scope and range of services. It now has operations in Cameroun, Côte d'Ivoire, Congo (Brazzaville), Guinea, Guinea-Bissau, Mauritania and Nigeria, as well as Senegal, and a sales office in France. In 2015, its head office was moved from London to Dubai. PCCI employs 3,000 people, including 1,400 in Senegal.

Call centres are still the core activity, including customer services for the 30 million clients of the MTN cell phone company in five African countries. However, PCCI provides a large number of other back-office services, including electronic document management portals, web portals, content management systems, email processing, and tele-surveys. Turnover is split between Europe (40 per cent) and Africa (60 per cent).

In its earlier days, the company faced many challenges associated with meeting international market requirements, especially pricing and service quality. Costs were high and there was also a severe skills shortage and no local institutions specialized in training tele-marketers. Labour turnover was high due to stiff competition for skilled workers. Today, the entry of the large French company, Atos, into Senegal is increasing the competition for IT engineers, which may make it more difficult for PCCI to expand its higher value-added services. Also the expansion of its domestic sales and the tightening of procedures may jeopardize its status as an Entreprise Franche d'Exportation, which allows it to import inputs duty- and VAT-free. For the moment, the authorities have made an exception for PCCI, even though their share of exports in total sales has fallen below the 80 per cent threshold normally required.

Source: ITC (2013); www.pcci-group.com; Groupe PCCI annonce l'ouverture de cinq nouveaux centres de contact, www.ict4africa.net.

Senegal is among the top 50 potential suppliers of outsourcing services according to the AT Kearney Global Services Location Index. However, it lies near the bottom-in $45^{\text {th }}$ place - and its ranking has fallen significantly in the last five years from $29^{\text {th }}$. Its financial attractiveness is not far behind the industry leaders, India and the Philippines, comparable to other African competitors, and it is well ahead of China and Malaysia, but Senegal has lost ground. The greatest weakness appears to be in the quality and quantity of human resources, and here too its attractiveness has declined. On the third criterion, the business environment, Senegal is not much behind India, and is making slow progress. Overall, Senegal has slipped behind Morocco and Mauritius, two of its main francophone rivals. 
Table 2: Outsourcing Alternatives - Industry Leaders and African Competitors: 2016

\begin{tabular}{lccccc}
\hline & $\begin{array}{c}\text { Financial } \\
\text { attractiveness }\end{array}$ & $\begin{array}{c}\text { People skills } \\
\text { and } \\
\text { availability }\end{array}$ & $\begin{array}{c}\text { Business } \\
\text { environment }\end{array}$ & $\begin{array}{c}\text { Overall } \\
\text { score }\end{array}$ & Rank \\
\hline India & 3.22 & 2.55 & 1.19 & 6.96 & 1 \\
China & 2.28 & 2.71 & 1.51 & 6.49 & 2 \\
Malaysia & 2.75 & 1.42 & 1.89 & 6.05 & 3 \\
Philippines & 3.17 & 1.43 & 1.29 & 5.88 & 7 \\
Ghana & 3.27 & 0.85 & 1.07 & 5.19 & 29 \\
Mauritius & 2.55 & 0.94 & 1.65 & 5.17 & 30 \\
Morocco & 2.80 & 0.93 & 1.34 & 5.07 & 34 \\
Tunisia & 3.04 & 0.82 & 1.18 & 5.05 & 38 \\
Kenya & 3.06 & 0.86 & 1.11 & 5.03 & 39 \\
Senegal & 3.06 & 0.70 & 1.13 & 4.89 & 45 \\
2016 & 3.23 & 0.78 & 1.11 & 5.12 & 29 \\
2011 & & & & & \\
\hline
\end{tabular}

Source: AT Kearney, Global Services Location Index (2011, 2016 editions).

Senegal's ranking is even lower when the focus is on telecommunications infrastructure and human resources, as measured by the International Telecommunications Union ICT Development Index. Senegal was ranked $132^{\text {nd }}$ in 2015 , up slightly from $137^{\text {th }}$ in 2010 , and only $12^{\text {th }}$ in sub-Saharan Africa. Clearly it has lost its leading role within the region.

By 2007, only 10 call centres and a handful of other IT-enabled service exporters remained. There has been little progress since then. A Technopole was established in Dakar to attract more companies but it failed to take off. In 2016, there were only nine call centres and they were finding it increasingly difficult to compete outside Senegal. Pressure on French companies to restrict foreign outsourcing appears to be part of the problem. Just three call centres accounted for 70 per cent of the market. Software development appears to be doing better, as solutions developed for Senegal are well-suited to other African contexts. The arrival of Atos is promising, although the competition for local IT engineers worries existing companies. ${ }^{29}$

The situation with regard to human resources is a mixed picture. Whereas the shortage of IT engineers is becoming a serious problem, call centres are able to hire university graduates from other disciplines, in contrast with France where they typically rely on high-school graduates. Call centres complain of high turnover and the need to train employees in-house, given the absence of such training in independent schools, but this is a common problem for call centres anywhere. The lack of English speakers is another constraint, although learning English is mandatory in high school and an increasing number of post-secondary programmes emphasize English, while some business schools teach exclusively in English. At the same time, Senegalese are moving to Morocco to work in call centres where they are better paid. This suggests that other constraints that increase costs are the bigger problem.

\footnotetext{
${ }^{29}$ Atos is a French leader in digital services with 93,000 employees in 72 countries. It was reported to be hiring the entire graduating class of IT engineers at the University of Dakar, as well as staff from other companies.
} 
Table 3: Cost of Internet Access per month: 2012

\begin{tabular}{lc}
\hline & Euros \\
\hline Tunisia & 7.0 \\
Egypt & 7.6 \\
Mauritius & 12.2 \\
Morocco & 12.2 \\
South Africa & 28.1 \\
Senegal & $\mathbf{3 8 . 1}$ \\
Ghana & 43.0 \\
\hline
\end{tabular}

Source: ITU as reported in ILEAP (2014).

The quality and cost of telecommunications infrastructure is also a mixed picture. Senegal had its first submarine fibre optic cable connection in 2000 and now has three. The internet bandwidth increased to 18.7 Gbit/second in 2013, making Senegal the largest internet portal in West Africa. However, the price is high compared to competitors in other regions. Table 3 provides a comparison of the monthly cost of fixed high-speed internet access.

The contrast between quality and cost reflects a wider characteristic of the telecommunications sector in Senegal. The principal investor in these fibre optic cables has been Sonatel, the former parastatal privatized in 1997. With the threat of increased competition, Sonatel reduced prices significantly in the early 2000s. But subsequently, it has been able to maintain a monopoly on external connectivity, and the number of internet service providers has fallen from nine in 2009 to two in $2012 .{ }^{30}$ The quality of basic telephone and internet services is reasonably good. But the speed of internet access, at 4.52 Mbps is below the average for sub-Saharan Africa (5.11) and much slower than Rwanda (9.5) or Kenya (7.3). ${ }^{31}$ The cost has failed to keep up with global trends, and other services, such as number portability and access to short numbers, are poor. Start-ups have been discouraged and Sonatel has been accused of taking over the most promising new ideas. ${ }^{32}$

Sonatel has grown to become the largest Senegalese company quoted on the regional stock exchange, expanding into Mali, Guinea and Guinea-Bissau. It is the largest taxpayer in Senegal, and since the state still owns 27 per cent of its shares, Sonatel is also a major source of dividends. Some of its staff go on to work for the regulatory agency, ARTP (Autorité de Régulation des Télécommunications et la Poste) which observers accuse of failing to promote greater competition. ${ }^{33}$ A new Telecommunications law was approved in 2011 but it did little to promote new internet service providers and the necessary implementation decrees to render it effective had still not been approved in early 2016. The political will for reform would appear to be lacking.

\footnotetext{
30 Sonatel had 99 per cent of the market for fixed high-speed internet access in 2012. A third company subsequently obtained access to a new submarine fibre optic cable but this is in partnership with Sonatel, who remain in control. Google (2013).

31 Ookla net index for 2014 as reported in World Bank (2015b).

32 Several of the internet service providers who closed attributed their failure to unfair competition by Sonatel. Google (2013: 21).

33 Google (2013: 30).
} 
In 2014, a meeting of all the stakeholders in the telecommunications sector was organized by the responsible Minister as part of the process of defining a new strategy. One of the participants spelled out the key question clearly:

Do you want to maintain the current situation where a few companies dominate the sector, the state receives large tax revenues, and employment increases slowly, or do you want to create a more competitive market where tax revenues fall in the short term, but 50 small start-ups are created in the next few years?

The Minister immediately spoke up in favour of the second option and a general consensus seemed to emerge. Unfortunately, the Minister soon resigned and the strategy process stalled.

In 2016, the strategy was being finalized and the government had stated that three new internet service providers would be allowed to enter the market. But at the same time, Sonatel's licence was up for renewal and the government was eager to raise additional revenues to finance its PES strategy. If the government wants to develop ICT exports, it will need to change its pro-Sonatel policy of the last 10 years and move quickly to keep up with competitors like Ghana and Kenya, who have adopted concerted strategies to promote ICT.

The PES acknowledges the need to improve the regulatory framework to guarantee fair competition and market entry for new players. This would be an essential first step. It also proposes the establishment of an ICT Board to strengthen the dialogue between the private and the public sectors. Finally, the PES suggests the creation of a specialized business park to attract firms engaged in business process outsourcing. A project is being developed with the AfDB to be located in the new city of Diamniadio on the outskirts of Dakar. ${ }^{34}$ It would be a good idea to hire a private company to manage the park, and to focus on the quality of services and infrastructure, notably a reliable energy supply, rather than on fiscal advantages.

\section{Conclusions}

Senegal is first and foremost a services economy, and is likely to remain so. Second, it is an agricultural society, though the economic role of agriculture is small given the low productivity levels and limited alternatives. Manufacturing is struggling and its most successful components derive from natural resources (phosphates, and limestone for cement). Labour-intensive manufactured exports are virtually non-existent. A new experiment with Chinese participation may start to turn this around, but such trade is likely to remain small. Senegal appears destined to become a major hydrocarbons exporter, though this may take many years and will never employ more than a small share of the growing labour force. It will likely undermine the country's competitiveness in labour-intensive exports.

Consequently, Senegal would be well-advised to build on its established experience in services such as tourism and IT-enabled exports, and to re-orient its agriculture to high value-added products like horticulture exports. These sectors could make an important contribution to the pressing challenge of job creation. Tourism and horticulture have significant potential to absorb

\footnotetext{
34 The proposed project is called the Parc de Technologies Numériques.
} 
low-skilled labour, and notably outside of Dakar where the opportunities are otherwise very limited. At the same time, they generate demand for some skilled labour and provide openings for local entrepreneurs. IT-enabled exports are more demanding and urban-based but offer an outlet for the growing number of graduates from higher education.

The PES clearly recognizes the need for a diversified export strategy with a strong focus on services. However, there remains a lack of solid sector-specific strategies. The new tourism strategy is weak; attention should probably be devoted to regional plans, starting with SalyPortudal and Casamance. The IT strategy has only just been finalized, and horticulture could benefit from a strategy; however Senegal has a long history of strategies with weak implementation. This will need to change.

When strategies are implemented, the Senegalese government tends to put itself in the driver's seat, expecting the private sector to follow. The relationship with the private sector is often unbalanced, with a tendency to privilege certain insiders while treating others with suspicion and occasionally harassment. The government needs to find a way to listen to and support serious players while sanctioning those who opt for rent-seeking. This need not require significant investments or fiscal incentives. Much can be done by reducing delays in VAT refunds, streamlining tax payments, reducing fiscal controls on low-risk taxpayers, avoiding mistakes like the new visa system, allowing greater flexibility in the use of short-term employment contracts, facilitating access to land, promoting Senegal as a tourist destination, and liberalizing the telecommunications sector.

Senegal will need to go beyond general improvements in the business climate, although this is important. Its high-level economic staff will need to develop a better understanding of the specific characteristics and constraints of the key sectors, and develop partnerships with private stakeholders to ensure that problems are addressed quickly and effectively. Regular sectoral meetings with the main exporters are needed to share concerns, agree on appropriate measures, and to promote accountability. And this will also require a new approach to collecting data, so that authorities know, for example, how much foreign leisure tourists actually spend in Senegal, what the value of horticulture exports really is, and how many people are employed in ITenabled services.

\section{References}

Banque Centrale des Etats de l'Afrique de l'Ouest (BCEAO) (2014). Balance des Paiements et Position Extérieur Global: Sénégal.

English, E.P. (1983). 'The Role of Tourism in the Economic Development of Senegal', PhD thesis, University of Toronto.

English, E.P. (1986). The Great Escape? An Examination of North-South Tourism. Ottawa: NorthSouth Institute.

Google (2013). 'Obstacles et Opportunités pour la Démocratisation de l'Internet Haut Débit au Sénégal', by Isabelle Gross for Balancing Act, commissioned by Google.

IMF (2005). 'VAT Refunds: A Review of Country Experience', by G. Harrison and R. Krelove, Working Paper WP/05/218. Washington, DC: IMF.

International Lawyers and Economists Against Poverty (ILEAP) (2014). 'Externalisation des processus d'affaires et services liés aux technologies de l'information: Étude de cas sur le Sénégal'. 
International Trade Center (ITC) (2013). 'LDC Services Exports: Trends and Success Stories', Technical Paper. Geneva: ITC.

Maertens, M., L. Cohen and J.F.M. Swinnen (2008a). 'Globalization and Poverty in Senegal: A Worst Case Scenario?'. Discussion Paper 217/2008. Leuven: LICOS Institute for Institutions and Economic Performance, Catholic University of Leuven.

Maertens, M., and J.F.M. Swinnen (2008b). 'Gender and Modern Supply Chains in Developing Countries'. Discussion Paper 231/2008. Leuven: LICOS Institute for Institutions and Economic Performance, Catholic University of Leuven.

République du Sénégal, Ministère du Tourisme (2003). 'Impact du Tourisme sur l'Economie sénégalaise: Rapport final' Madrid.

République du Sénégal, Ministère des Finances, de l'Economie et du Plan (2015). 'Point Mensuel de Conjoncture', Décembre.

World Bank (2013). 'Stratégie de Développement de l'Economie Numérique du Sénégal'. By Kalba International, Inc. commissioned by the World Bank. Washington, DC: World Bank.

World Bank (2014). 'Senegal Economic Update: Learning from the Past for a Better Future'. Washington, DC: World Bank.

World Bank (2015a). 'Senegal: Exports and Competitiveness Project Appraisal Document'. draft. Washington, DC: World Bank.

World Bank (2015b). 'Note on the Information and Telecommunications Sector in Senegal'. Washington, DC: World Bank.

World Bank (2016). 'Senegal Economic Update: Do What You Do Best - Communicate and Trade'. Washington, DC: World Bank. 